\title{
Effects of soil characteristics and spring management on the persistence of 'Grasslands Matua' prairie grass
}

\begin{abstract}
'Grasslands Matua' prairie grass was direct drilled into easy hill county at Whatawhata Research Centre. Establishment was excellent, but persistence was poor in most paddocks after 2 years. Site conditions associated with a range of Matua populations were surveyed. Matua population decline was greatest during spring. Spring soil nitrogen levels were associated with persistence, implying that nitrogen application in late winter may enhance persistence. In a trial to assess the effect of spring management on tillering patterns, seed production and seedling vigour, October closing resulted in the highest seed production, seed vigour and highest tiller density after herbage removal. It is proposed that a springsummer hay making policy will enhance the vigour of the existing population and provide adequate reseeding for new plant recruitment.
\end{abstract}

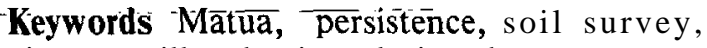
nitrogen, tiller density, closing date

\section{Introduction}

'Grasslands Matua' prairie grass (Bromus willdenowii Kunth) has been widely advocated at having good growth potential during winter-early spring and late summer (Fraser 1985; Ridler 1986). However, its persistence has often been poor especially on poorly drained soils, or with mismanagement or insect damage (Hockings 1979; Sellars 1988; Thorn et al. 1989).

In spring 1986, Matua prairie grass, 'Grasslands Pitau' white clover and 'Grasslands Pawera' red clover were successfully established in 24 paddocks within a farmlet experiment at Whatawhata Research Centre (Webby et al. 1990). Matua seed was direct drilled into sprayed pasture (Roundup 3 l/ha). Pitau and Pawera seeds were broadcast over the drill rows before harrowing. These paddocks were considered the most fertile and of easiest contour within hill country, with an annual production of $14000 \mathrm{~kg}$ DM/ha. Soil types varied between yellow-brown loams, brown-granular loams and yellow-brown earths (Dunmore, Naike and Kaawa, respectively; Bruce 1978). By autumn 1989, Matua content in these pastures was variable, but generally poor. All had received similar grazing management within a breeding ewe-bull finishing system.

Variation in Matua content within the Whatawhata farmlets provided a unique opportunity to study possible links between Matua persistence and soil conditions. The possible rejuvenation of Matua pastures through reseeding was also considered by studying spring management effects on tiller populations, seed production, and on the resultant seedling vigour. Management options were viewed within the context of an animal finishing system.

\section{Methods}

\section{Matua persistence survey}

In November 1988, 12 of the 24 established Matua paddocks were grouped into 3 classes on the basis of Matua content: good (35\% of pre-graze DM during Nov-Dee), medium $(15 \%)$ and poor $(10 \%)$. The paddocks $(0.23-0.50 \mathrm{ha})$ were of various aspects. and had average slopes of $0-15^{\circ}$

Within each paddock, three $1 \mathrm{~m} \times 0.8 \mathrm{~m}$ plots were selected to represent high, medium and low Matua density areas. The medium plot was also representative of the paddock for aspect, fertility and slope. In this way both between- and within-paddock variation could be considered.

In December 1988, plots were assessed for Matua content by a point analysis technique ( $\%$ frequency of hits, Radcliffe \& Mountier 1964), and soil samples $(\mathrm{O}-7.5 \mathrm{~cm}$ and $7.5 .15 \mathrm{~cm})$ were taken for $\mathrm{pH}, \mathrm{Ca}$, phophate, K,S, Na, Mg (MAF quick-test: Cornforth et al. 1984), total organic $\mathrm{N}$, phosphate retention and organic C' levels (Blackmore et al. 1987). In September 1989, plots were resampled for bulk density, inorganic $\mathrm{N}$ and mineral $\mathrm{N}$ after anaerobic incubation.

Variation (between and within paddock) was analysed by analysis of variance, simple correlation and multiple regression using Matua content and soil data.

\section{spring reseeding trial}

In spring 1988, in a uniform area of Matua-dominant pasture, three spring management policies were 
Table 1 Average composition in Matua pastures within the farmlet experiment of Webby et al. (1990) (\% dry weight of green leaf and stem fractions).

\begin{tabular}{lccccccrr} 
& \multicolumn{2}{c}{1987} & \multicolumn{2}{c}{1988} & \multicolumn{2}{c}{1989} & \multicolumn{2}{c}{ Summer Autumn } \\
\hline Matua $\%$ & Winter & Spring & Summer Autumn Winter & Spring & $\mathbf{9}$ \\
Other grass & $\mathbf{7 0}$ & $\mathbf{4 3}$ & $\mathbf{2 5}$ & $\mathbf{5 2}$ & $\mathbf{5 0}$ & $\mathbf{3 3}$ & $\mathbf{2 1}$ & $\mathbf{9}$ \\
Lenume $\%$ & $\mathbf{4}$ & $\mathbf{1 2}$ & $\mathbf{1 6}$ & $\mathbf{1 2}$ & $\mathbf{2 0}$ & $\mathbf{4 4}$ & $\mathbf{4 4}$ & $\mathbf{3 5}$ \\
\hline
\end{tabular}

compared: October close (6 Ott-21 Dec), November close $(9$ Nov-21 Dec) and No close (4 weekly defoliation). These were replicated 5 times. Until the appropriate closing date, plots $(6 \mathrm{~m} \times 2 \mathrm{~m})$ were mown monthly to a height of $4 \mathrm{~cm}$.

Within each plot, 5 random quadrats $\left(0.06 \mathrm{~m}^{2}\right)$ were permanently located and Matua reproductive and vegetative tiller numbers counted fortnightly from late October to late December. Seed was harvested from the quadrats in late December. Plots were then mown and grazed to a $4 \mathrm{~cm}$ height and tiller numbers assessed 3 and 7 weeks later.

Closing date treatments were compared by analysis of variance of mean plot values. Within plot, quadrat data provided an opportunity to regress Matua tiller density and seed yields.

\section{Seed vigour assessment}

Seed lines collected from two of the spring reseeding treatments (October and November closing) were compared for seedling vigour against two commercially harvested "standard" seed lines: a breeders' seed line provided by DSIR Grasslands, and a line obtained from a commercial seed merchant.

Seed was treated with fungicides (Baytan and Captan) and placed on wet filter paper. Germination was assessed daily. As seeds developed a radicle, they were planted into flats $(300 \times 200 \times 50 \mathrm{~mm})$ at 15 seeds per flat. This was replicated 5 times. The No close treatment failed to germinate sufficient seed to allow vigour comparisons. Seedlings were grown in an unheated glasshouse from early March to early May. At 3, 6 and 8 weeks from imbibition, one third of the plants in each seed line were harvested, dried and weighed.

Analysis of variance was performed on the data.

\section{Results and discussion}

Matua persistence survey

Changes with time The pre-grazing composition $\mathbf{( \% \mathbf { 0 }}$ of DM) of Matua pastures, indicates the changes in Matua content during 1987-89 (Table 1). Decreases were most marked in spring 1987 and in spring and summer 1988-89. Perennial ryegrass and Poa spp. were the main grass successors.

The decline in Matua population in summerautumn 1989 can be attributed to insect attack. Hessian fly (Mayetiola destructor Say) and Argentine stem weevil (Listronotus bonariensis (Kuschel)) were present in all 24 paddocks. Thorn et al. (1989), in a study $25 \mathrm{~km}$ away, found that tiller death due to hessian fly peaked at $82 \%$ during late summer. Seedling prairie grass was very susceptible to Argentine stem weevil attack. Because of seasonal life cycles and activity, insect damage cannot be considered as the cause of the mid-spring declines.

Between-paddock variation Paddocks with the highest Matua content in December 1988 were located predominantly on lighter, free-draining ash soils (yellow-brown loams) with generally higher nutrient status (Table 2). Poorer Matua pastures were on the heavier soil types with lower nutrient levels. Physical and chemical effects are difficult to separate as they are confounded by soil type differences, but with the exception of phosphate levels in medium paddocks, mineral nutrient status would be considered adequate for satisfactory ryegrass-white clover growth (Cornforth et al. 1984; Clough 1990). The importance of good drainage for Matua persistence has been highlighted by Sellars (1988), and the free-draining ashrderived soils within this experimental area appeared to benefit Matua.

Table 2 Matua survey: between-paddock variation (soil tests on 0-7.5 $\mathrm{cm}$ depth).

\begin{tabular}{|c|c|c|c|c|c|}
\hline Matua & $\begin{array}{l}\text { Good } \\
\text { Content }\end{array}$ & $\begin{array}{l}\text { Medium } \\
\text { Content }\end{array}$ & $\begin{array}{c}\text { Poor } \\
\text { Content }\end{array}$ & SED & Sig \\
\hline $\begin{array}{l}\% \text { frequency of Matua } \\
\% \text { composition }\end{array}$ & 41.7 & 20.7 & 6.8 & 5.7 & *** \\
\hline (Matua dry weight) & 35.1 & 15.3 & 9.9 & - & - \\
\hline $\mathrm{pH}$ & 5.6 & 5.4 & 5.4 & 0.11 & NS \\
\hline Olsen P & 24.5 & 12.0 & 16. 7 & 3.4 & \$* \\
\hline Sulphate & 26.7 & 16.7 & 14.0 & 3.1 & ** \\
\hline $\mathrm{K}$ & 18.0 & 14.5 & 7.0 & 5.0 & NS \\
\hline $\begin{array}{l}\% \text { Organic } \mathrm{C} \\
\% \text { Total organic } \mathrm{N}\end{array}$ & $\begin{array}{l}9.8 \\
0.86\end{array}$ & $\begin{array}{r}6.8 \\
0.60\end{array}$ & $\begin{array}{r}5.7 \\
0.52\end{array}$ & $\begin{array}{r}1.2 \\
0.11\end{array}$ & $*$ \\
\hline Spring inorganic $\mathrm{N}(\mu \mathrm{g} / \mathrm{g})$ & 5.4 & 3.5 & 3. $9^{\prime}$ & 1.0 & NS \\
\hline Spring incubation $\mathrm{N}(\mu \mathrm{g} / \mathrm{g})$ & 166 & 84 & 122 & 37 & NS \\
\hline$\%$ Phosphate retention & 82.8 & 64.0 & 46. 2 & 10.9 & $\cdot$ \\
\hline Bulk density $(\mathrm{g} / \mathrm{ml})$ & 0.71 & 0.88 & 0.95 & 0.05 & ** \\
\hline
\end{tabular}


Table 3 Matua survey: within-paddock variation (soil tests on 0-7.5 cm depth).

\begin{tabular}{|c|c|c|c|c|c|}
\hline & High & Medium & Low & SED & Sig \\
\hline$\%$ frequency of Matua & 64.6 & 33.9 & 8.2 & 3.7 & *** \\
\hline $\begin{array}{l}\mathrm{pH} \\
\text { Olsen } \mathrm{P}\end{array}$ & $\begin{array}{l}5.46 \\
33.4\end{array}$ & $\begin{array}{l}5.48 \\
23.2\end{array}$ & $\begin{array}{l}5.45 \\
13.8\end{array}$ & $\begin{array}{l}0.07 \\
4.0\end{array}$ & $\underset{* *}{N S}$ \\
\hline Sulphate & $\begin{array}{l}36.6 \\
19.9\end{array}$ & $\begin{array}{l}24.1 \\
14.1\end{array}$ & $\begin{array}{l}17.0 \\
8.9\end{array}$ & $\begin{array}{l}6.2 \\
2.7\end{array}$ & $*$ \\
\hline$\%$ Organic $\mathrm{C}$ & 10.0 & 8.9 & $\begin{array}{l}0.9 \\
6.6\end{array}$ & 0.91 & $* *$ \\
\hline$\%$ Total organic $\mathrm{N}$ & 0.86 & 0.78 & 0.54 & 0.09 & $\bullet$ \\
\hline Spring inorganic $\mathrm{N} \& \mathrm{~g} / \mathrm{g}$ ) & 6.49 & 4.69 & 4.47 & 0.36 & **** \\
\hline Spring incubation N @g/g) & 148 & 137 & 112 & 17.2 & NS \\
\hline \% Phosphate retention & 76.1 & 78.1 & 60.6 & 6.4 & $\bullet$ \\
\hline Bulk density $(\mathrm{g} / \mathrm{ml})$ & 0.72 & 0.77 & 0.91 & 0.04 & ** \\
\hline
\end{tabular}

Eccles et al. (1990) demonstrated the physiological sensitivity of Matua to waterlogging, but supersaturation of the soil was not common even for the heavier yellow-brown earths.

Within-paddock variation Areas of medium Matua content could be considered as being representative of the general paddock condition (Table 3). Matua content was regularly high on high fertility stock camp areas. In hill country, up to $70 \%$ of dung and urine may be deposited on selected camp areas. Consistently, areas with high Matua content had higher organic and mineral nutrient status than medium content areas. The greatest differences in phosphate retention and bulk density occurred between medium and low content areas. Those factors most strongly correlated with Matua content were considered in a multiple regression analysis. The following equation explained $72 \%$ of the encountered variation and is a good indicator of likely persistence with-in this-experimental environment:

Matua content $=-36.8+0.64$ Olsen $\mathrm{P}+5.39$ Inorganic $\mathrm{N}+5.39 \%$ Organic $\mathrm{C}+-0.44 \%$ Phosphate Retention.

Phosphate retention was negatively correlated with bulk density $(T=-0.91)$, which reflected the volcanic ash content of the soil.

\section{Plant vigour}

Matua content declined during spring. Within mixed pastures of volunteer ryegrass and Poa, Matua vigour was poor and plants were commonly of 2-3 tillers. In such plants in October, most tillers became reproductive and were grazed; and few residual tillers were available for regrowth. We suggest that Matua decline in spring was associated with its poor competitive ability under the general $\mathrm{N}$ conditions that prevailed. Greater persistence within high fertility stock camps and on free-draining ash soils where organic matter and better aeration would have provided high mineral $\mathrm{N}$ status, supports this suggestion.

While Matua has similar response patterns to that of perennial ryegrass for $\mathrm{P}, \mathrm{S}$ and $\mathrm{K}$, it is more responsive at high levels of $\mathrm{N}$ (Clough, pers. comm.). Dodd et al. (1990) also showed that $\mathrm{N}$ applications in early winter improved Matua plant vigour, size and subsequent persistence. It is proposed that $\mathrm{N}$ applied to Matua pastures in August would benefit Matua persistence where perennial ryegrass and Poa spp. are aggressive competitors. Such an application would improve Matua's competitiveness and would also encourage greater tiller numbers as plants move into their reproductive phase. This hypothesis requires testing.

Within the constraints of the animal finishing systems being studied (Webby et al. 1990), spring grazing management would not have benefited Matua vigour and competitive ability. Black \& Chu (1989) highlighted the importance of timely grazing So that replacement tillers are available for immediate regrowth after grazing. Bull grazing pressure (2.9 and $1.4 \mathrm{t} \mathrm{DM} / \mathrm{ha}$ for pre- and post-grazing) was also much more intense than that recommended by Ridler et al. (1988). More timely and lax grazing may have improved Matua vigour but this was not practical within the-finishing-systems used.

Spring decline may be of less rêlêvance where environmental conditions do not favour high ryegrass content (e.g. summer drought). However, where Matua was successfully established on easier contoured, higher fertility paddocks in hill country, conditions were clearly unsuitable. Even the best paddocks failed to retain more than $30 \%$ pre-graze $\mathrm{DM}$ as Matua.

\section{Reseeding}

Spring management trial Seed production was highest where matua plots were closed after defoliation in early October (Table 4). The No close treatment produced little seed. Seed yields in this treatment would be lower than in regularly grazed pastures, as defoliation of reproductive tillers would have been more complete under the mowing regime used.

After seed harvest in late December, all plots received a "clean-up" cut and graze. Subsequent tiller populations were greatest in the October close treatment. The No close treatment had the poorest tiller population in January, even though this treatment had the highest number of vegetative tillers in late December. Strong white clover growth in the 
Table 4 Seed production and Matua tiller densities.

\begin{tabular}{|c|c|c|c|c|c|c|c|c|}
\hline \multirow{3}{*}{$\begin{array}{l}\text { Seed yield } \mathbf{g} / \mathrm{m}^{2} \\
\text { Seed number } \mathrm{m}^{2} \\
\text { Tiller density } / \mathrm{m}^{2}\end{array}$} & \multirow{2}{*}{\multicolumn{4}{|c|}{$\begin{array}{c}\text { Closing date } \\
\text { November } \\
50.0 \\
7503 \\
\end{array}$}} & \multirow{2}{*}{\multicolumn{2}{|c|}{$\begin{array}{c}\text { No closing } \\
2.6 \\
774\end{array}$}} & \multicolumn{2}{|c|}{ SED/Sig } \\
\hline & & & & & & & $\begin{array}{c}9.6 \\
1578 \\
\end{array}$ & $\begin{array}{l}* * * \\
* * *\end{array}$ \\
\hline & $\begin{array}{c}\text { Repro } \\
\text { tillers }\end{array}$ & $\begin{array}{l}\text { Vege } \\
\text { tillers }\end{array}$ & $\begin{array}{l}\text { Repro } \\
\text { tillers }\end{array}$ & $\begin{array}{l}\text { Vege } \\
\text { tillers }\end{array}$ & $\begin{array}{c}\text { Repro } \\
\text { tillers }\end{array}$ & $\begin{array}{l}\text { Vege } \\
\text { tillers }\end{array}$ & $\begin{array}{l}\text { Repro } \\
\text { tillers }\end{array}$ & $\begin{array}{l}\text { Vege } \\
\text { tillers }\end{array}$ \\
\hline $25 / 10$ & 551 & 457 & $\begin{array}{l}581 \\
\text { cut }\end{array}$ & $\begin{array}{l}468 \\
\text { cut }\end{array}$ & $\begin{array}{l}539 \\
\text { cut }\end{array}$ & $\begin{array}{l}480 \\
\text { cut }\end{array}$ & $64 \mathrm{NS}$ & $52 \mathrm{NS}$ \\
\hline $24 / 11$ & 582 & 512 & 252 & 865 & $\begin{array}{r}299 \\
\text { cut }\end{array}$ & $\begin{array}{l}760 \\
\text { cut }\end{array}$ & $42^{* * *}$ & $69 * *$ \\
\hline $21 / 12$ & $\begin{array}{l}475 \\
\text { cut }\end{array}$ & $\begin{array}{l}773 \\
\text { cut }\end{array}$ & $\begin{array}{l}254 \\
\text { cut }\end{array}$ & $\begin{array}{l}431 \\
\text { cut }\end{array}$ & $\begin{array}{r}41 \\
\text { cut }\end{array}$ & $\begin{array}{l}845 \\
\text { cut }\end{array}$ & $49^{* * *}$ & $99 * *$ \\
\hline $\begin{array}{r}10 / 1 \\
7 / 2\end{array}$ & $\begin{array}{l}0 \\
0\end{array}$ & $\begin{array}{r}1148 \\
568\end{array}$ & $\begin{array}{l}0 \\
0\end{array}$ & $\begin{array}{l}706 \\
397\end{array}$ & $\begin{array}{l}0 \\
0\end{array}$ & $\begin{array}{l}703 \\
242\end{array}$ & $153^{*}$ & $70^{* *}$ \\
\hline
\end{tabular}

No close plots may have contributed to this poorer Matua recovery.

The within-plot variation of tiller numbers in October was linked closely with seed yields (Figure 1). The potential to produce seed from similar tiller populations was never realised, as later closings reduced the proportion of reproductive tillers (Table 4).

Specialist seed crop management of Matua can provide yields of 2.0 t/ha (Brown \& Archie 1986;

Brown \& Rolston 1985). Early October closing in this experiment provided a potential reseeding yield of $1000 \mathrm{~kg} / \mathrm{ha}$. This treatment also provided established plants with the best opportunity to regrow after cutting and grazing in late December. This policy would fit well into a hay making, spring management practice which would ensure excellent seed shatter. It would also fit well into farm systems that have surplus feed during November-December and a shortage of quality feed during January-February. Certainly, hard grazing in late spring would not encourage sufficient reseeding, and would reduce summer vigour of established Matua plants.

Seed weight and vigour While seed inputs from natural reseeding can be high, the ultimate success of a rejuvenation programme will depend on seed germination and seedling vigour. Both the commercial and breeders' seed lines had higher seed weights, faster germination and better seedling vigour than the trial-harvested seed lines (Table 5). Of the three trial seed lines, the October close treatment showed the highest seed weight, germination and seedling vigour. The 3- and 6-week harvest dates provided the best indication of vigour, as interplant competition and plot variation increased as the trial progressed.

How well the seed from the October and November close treatments represents the condition of seed produced from a general pasture is difficult to ascertain. Nevertheless, seed collected from this experiment was markedly inferior to that of the "breeders" and commercial lines. Relative to sown

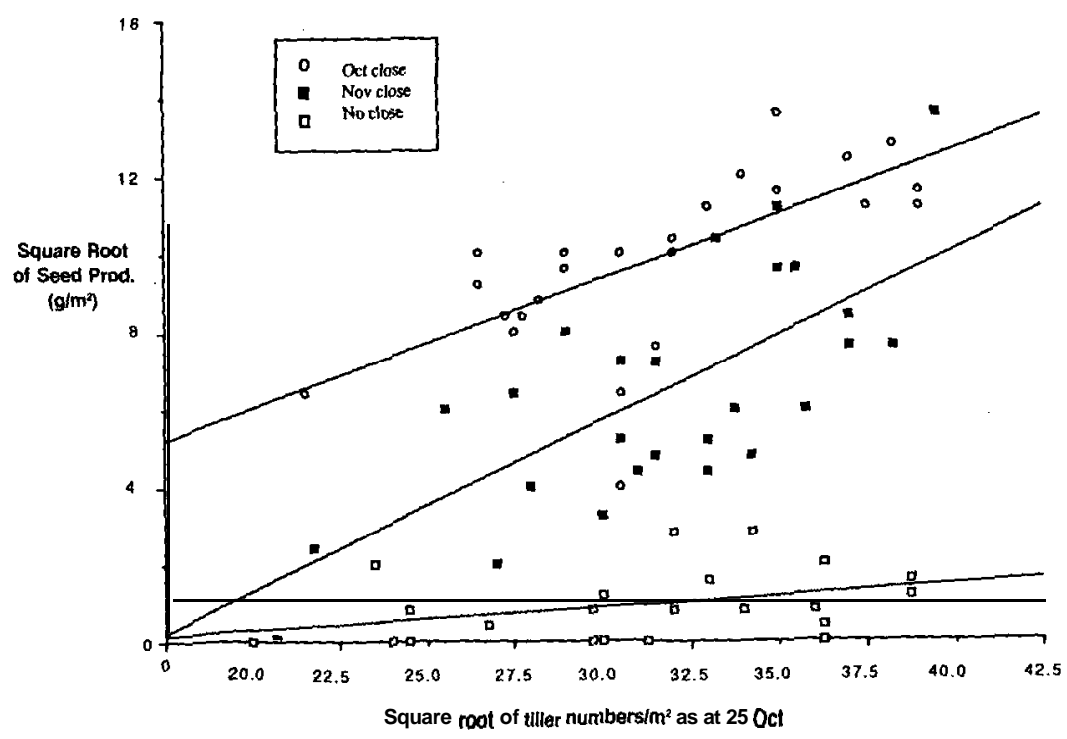

Figure 1 Seed production $v$, tiller numbers. 
Table 5 Seed characteristics (weight and germination) and seedling weights (g/plant).

\begin{tabular}{|c|c|c|c|c|c|c|c|}
\hline & $\begin{array}{l}\text { Oct } \\
\text { close }\end{array}$ & $\begin{array}{l}\mathrm{Nov} \\
\text { close }\end{array}$ & $\begin{array}{l}\text { No } \\
\text { close }\end{array}$ & Commercial & Breeders & SED & Sig \\
\hline $\begin{array}{l}1000 \text { seed wt. }(\mathrm{g}) \\
\% \text { germination }\end{array}$ & 6.95 & 6.42 & 2.76 & 9.94 & 11.55 & - & - \\
\hline $\begin{array}{l}9 \text { days } \\
\% \text { germination }\end{array}$ & 17.0 & 8.0 & 0 & 17.7 & 27.7 & 9.38 & NS \\
\hline $\begin{array}{l}\text { @ } 31 \text { days } \\
3 \text { week harvest }\end{array}$ & 63.7 & 51.0 & 6.3 & 86.0 & 62.7 & 9.19 & $*$ \\
\hline $\begin{array}{l}\text { (g/plant) } \\
\text { 6-week harvest }\end{array}$ & 0.0102 & 0.0075 & $\Rightarrow$ & 0.0219 & 0.0265 & 0.0046 & ** \\
\hline (g/plant) & 0.339 & 0.266 & - & 0.493 & 0.488 & 0.074 & * \\
\hline $\begin{array}{l}\text { 8-week harvest } \\
\text { (g/plant) }\end{array}$ & 0.723 & 0.651 & $=$ & 0.933 & 0.902 & 0.198 & NS \\
\hline
\end{tabular}

seed, this inferiority would disadvantage establishment of new plants within a reseeded, competitive pasture. While October close management was never practised by Webby et al. (1990), Matua seedlings were very common in each autumn-winter but were unable to survive the competitive and treading stresses of 50- to 60-day winter grazing rotations.

\section{Conclusions and recommendations}

Matua failed to maintain vigour and successfully compete against other grasses during spring when soil $\mathrm{N}$ was low. We suggest that $\mathrm{N}$ application in late winter may encourage Matua persistence in swards where ryegrass competition is strong.

Excluding grazing from Matua pastures during October to December (e.g. hay making policy) enhances the density of existing populations and ensures adequate reseeding for new plant recruitment.

\section{REFERENCES}

Black, C.K.; Chū, A.C.P. 1989. Searirching for an alternative way to manage prairie grass. Proceedings of the $N Z$ Grassland Association 50: 219-223.

Blackmore, L.C.; Searle, P.L.; Daly, B.K. 1987. Methods for chemical analyses of soils. Scientific Report 80, NZ Soil Bureau.

Brown, K.R.; Archie, W.J. 1986. Seed production studies in "Grasslands Matua" prairie grass (Bromus willdenowil). NZ journal of experimental agriculture 14: $261-269$.

Brown, K.R.; Rolston, M.P. 1985. Effect of management on seed recovery and seed yield of Bromus willdenowii. Proceedings of the $X V t h$ International Grassland Congress: 307309;

Bruce, J.G. 1978. Soils of part Raglan Country, South Auckland. Soil Bureau Bulletin 41.
Clough, T.J. 1990. Response of Yatsyn ryegrass, Matua prairie grass and Wana cocksfoot to phosphorus and potassium. Proceedings of the NZ Grassland Association 51: 167-170.

Cornforth, I.S.; Sinclair, A.G. 1984. Fertiliser and lime recommendations for pastures and crops in NZ

Dodd, M.B.; Chu, A.C.P.; Matthews, P.N.P. 1990. Can we reverse the process of deterioration in a prairie grass pasture? Proceedings of the NZ Grassland Association 51: 123-126.

Eccles, W. J.; Matthew, C.; Chu, A.C.P. 1990. Response to Matua prairie grass and Ellet perennial ryegrass to excess soil moisture in sand, silt and clay soils. Proceedings of the NZ Grassland Association 51: 127-130.

Fraser, T.J. 1985. Role of Matua prairie grass in an all grass system for prime lamb production. Proceedings of the NZ G rassland Association 46: 157- 167.

Hocking, B. 1979. Advice for those contemplating Matua prairie ... Don't. NZ Farmer, 8 February: 91-92.

Radcliffe, J.E.; Mountier, N.S. 1964. Problems in measuring pasture composition in the field - Part I Discussion of general problems and some considerations of the point method. NZ journal of botany 2: 90-97.

Ridler, B.J. 1986. Experience with Matua at No. 4 Dairy farm. Publication No. 3, Massey Farm Series, "Matua Prairie Grass", pp 15-25.

Ridler, -B.J.; Stachurski; - L.J.;- Brookes, I.M. 1988: Incorporation of Matua prairie grass into grazing systems. Proceedings of the NZ Grassland Association 49: $181-184$

Sellars, M.D. 1988. Manawatu dairy farmers experience with Matua prairie grass. Proceedings of-the NZ Grassland Association 49: 185- 186.

Thorn, E.R.; Prestidge, R.A.; van der Zijpp, S. 1989. Effects of pests and diseases on prairie grass production under dairying in the Waikato region of New Zealand. Proceedings of the 5th Australasian conference on grassland invertebrate ecology: 3 14-322.

Webby, R.W.; Sheath, G.W.; Boom, C.J. 1990. Performance of new pasture cultivars in a hill country finishing system. Proceedings of the NZ Grassland Association 5l: 181-186. 